\title{
Advanced Oxidation Processes for Wastewater Treatment in the Pulp and Paper Industry: A Review
}

\author{
Laura G. Covinich", ${ }^{1, *}$ Dora I. Bengoechea ${ }^{1}$, Rosa J. Fenoglio ${ }^{2}$, María C. Area ${ }^{1}$ \\ ${ }^{1}$ Programa de Celulosa y Papel - Instituto de Materiales de Misiones. Universidad Nacional de Misiones (UNaM) - Consejo Nacional de \\ Investigaciones Científicas y Técnicas. (CONICET). Félix de Azara 1552 (3300), Posadas, Misiones, Argentina \\ ${ }^{2}$ Dpto. de Ingeniería Química/Div. Catalizadores y Superficies, Instituto de Investigaciones en Ciencia y Tecnología de Materiales, \\ INTEMA (UNMdP-CONICET), Juan B. Justo 4302 (7600), Mar del Plata, Argentina
}

\begin{abstract}
The effluents of some pulp and paper processes are potentially pollutant, because of their large volume and their refractory nature. Biological processes generally are not capable to remove these compounds. Advanced Oxidation Processes (AOP) are characterized by the capability of exploiting the high reactivity of $\mathrm{HO}$ - radicals. AOP can produce a total mineralization, transforming recalcitrant compounds into inorganic substances $\left(\mathrm{CO}_{2}\right.$ and $\left.\mathrm{H}_{2} \mathrm{O}_{2}\right)$, or partial mineralization, transforming them into more biodegradable substances. The high reactivity and low selectivity of these radicals are useful attributes that that make these processes in promising technologies. Due to the differences between pulping processes, the effluents from the various processes and operations of such industries also differ from each other, so that some oxidative processes should be combined to improve the removal efficiency. For the effective oxidation of refractory organic compounds, hydroxyl radicals should be generated continuously in situ due to its chemical instability. Generation of $\mathrm{HO} \bullet$ is commonly accelerated by combining oxidizing agents. Among these treatments, UV radiation plus hydrogen peroxide $\left(\mathrm{UV} / \mathrm{H}_{2} \mathrm{O}_{2}\right)$, Fenton's reagent $\left(\mathrm{H}_{2} \mathrm{O}_{2} / \mathrm{Fe}^{+2}\right)$, photo-Fenton $\left(\mathrm{UV} / \mathrm{H}_{2} \mathrm{O}_{2} / \mathrm{Fe}^{+2}\right)$, and ozone in different combinations $\left(\mathrm{O}_{3} / \mathrm{UV}\right.$; $\mathrm{O}_{3} / \mathrm{H}_{2} \mathrm{O}_{2}$ ) are considered to be effective for the oxidation of effluents from pulp and paper industries.
\end{abstract}

Keywords Advanced Oxidation Processes, COD removal, Pulping effluent, Recalcitrant compounds

\section{Introduction}

The pulp and paper industry has been considered as one of the biggest consumers of natural resources (wood, water), energy (electricity and fossil fuels) and as major contributor of pollutants discharge to the environment. As a result of pulping and manufacture of paper products, it generates a large amount of contaminants, whose composition varies depending on the manufacturing process [1]. The objective of all pulping processes is to separate the fibers, producing a fiber suspension in water. This separation can be accomplished by applying mechanical, thermal, and chemical energy, in different proportions [2].

Depending on the process, the most important sources of contamination from the different stages of the process are: wood preparation, pulping, pulp washing, screening, bleaching, papermaking and coating operations [3].

The characteristics of the waste liquid to be treated depends on the type of wood, the type of process, the amount of water that the mill is able to circulate, the technology used and the selected management practices. Depending on the

* Corresponding author:

covinich_laura@yahoo.com.ar (Laura G. Covinich)

Published online at http://journal.sapub.org/ajee

Copyright (C) 2014 Scientific \& Academic Publishing. All Rights Reserved raw material and the process involved, untreated waste fluids can have high biochemical oxygen demand (BOD), chemical oxygen demand (COD), suspended solids (mainly fibers), fatty acids, tannins, resin acids, lignin, and its derivatives. Some of them are naturally occurring pollutants and others are xenobiotics, which are formed during the pulp and paper manufacturing process [4], [5]. Some substances are recalcitrant to biological degradation and toxic to aquatic species. Some bleaching processes even generate bioaccumulative compounds [6], [7].

The wastewaters of high yield pulping processes are characterized by their suspended solids content (including particles of bark), organic substances, chromophoric compounds (mainly labile extractives and lignin fragments), inorganic compounds (nitrogen and phosphorus, as result of the effluent treatment) and salts. Semichemical processes contain lignosulfonates (derived from lignin) in addition to the above. The Kraft process wastewaters are characterized by their content of solids (including particles of bark), dissolved organics, chromophoric compounds (mainly derived from lignin). If Kraft pulps are bleached with chlorine compounds, they can present organochlorine compounds (dioxins and furans) [8].

Although chromophoric groups are not well defined, they are basically composed by conjugated olefins and quinones, methidic quinones and aromatic rings. While bleaching of 
high yield processes uses oxygen as oxidizing agent, in the case of Kraft pulps, chlorine was historically used. The improvements that have been made in the bleaching process in the last 20 years consisted on the complete removal of elemental chlorine by developing technologies as Elemental Chlorine Free (Elemental Chlorine Free, ECF) or Totally Chlorine Free (Totally-Chlorine Free, TCF), combined with oxygen delignification, which reduces the amount of organochlorine compounds released into the environment [9].

The initial values of COD of pulping processes are very different, depending on the origin of the effluent and the type of raw material. For example, the content of phenolic compounds and chlorinated compounds in the wastewater of hardwood Kraft pulping is three to eight times smaller than that of the softwood Kraft pulping [10]. Examples of initial COD of high yield pulping [TMP, CTMP, BCTMP, and NSSC] and Kraft pulping are shown in Table 1.

Table 1. COD of effluents from high yield and chemical pulping processes

\begin{tabular}{|c|c|c|c|}
\hline Effluent & Process & COD $[\mathrm{mg} / \mathrm{L}]$ & Reference \\
\hline \multirow{6}{*}{ Pulp mills } & TMP & $\begin{array}{c}3340 ; 3500 ; 5600 \\
7210 ; 3340\end{array}$ & $\begin{array}{l}{[12]} \\
{[13]}\end{array}$ \\
\hline & ВCTMP-TMP & $2520 ; 7930$ & [12] \\
\hline & TMP-CTMP & 4000 y 7800 & [12] \\
\hline & CTMP & $\begin{array}{c}4800 ; 7900 ; \\
6000-9000 ; 12000\end{array}$ & [12] \\
\hline & NSSC & $1000-5600$ & {$[12]$} \\
\hline & Kraft bleaching & $\begin{array}{l}500-700 ; 1100- \\
1700 ; 1254 ; 1200\end{array}$ & $\begin{array}{l}{[14],[15],} \\
{[16],[17]}\end{array}$ \\
\hline \multirow{4}{*}{$\begin{array}{l}\text { Pulp and } \\
\text { paper } \\
\text { mills }\end{array}$} & TMP & $1000-5600$ & [12] \\
\hline & CTMP & $\begin{array}{c}2500-13000 \\
9521\end{array}$ & [12], [18] \\
\hline & NSSC & 5020 & {$[12]$} \\
\hline & Kraft & $\begin{array}{l}1000 ; 1400 ; \\
2210 ; 1130\end{array}$ & $\begin{array}{l}{[3],[19],} \\
{[16],[20]}\end{array}$ \\
\hline
\end{tabular}

TMP: Thermomechanical pulping, CTMP: chemithermomechanical pulping, BCTMP: Bleached chemithermomechanical pulping, NSSC: neutral sulfite semichemical process

\section{Advanced Oxidation Processes}

Conventional technologies including biological, thermal, and physicochemical treatments have been traditionally used to remove aqueous contaminants. Some other techniques such as flocculation, precipitation, adsorption, extraction, and reverse osmosis required post-treatments to dispose the separated contaminants. These limitations of conventional methods have been an incentive to develop more efficient systems. Since some of the pollutants in industrial effluents are not biodegradable, conventional treatment processes are not sufficient. In order to meet the increasingly stringent discharge limits, mills are forced to adopt unconventional and technologically advanced treatment systems to reduce refractory organic compounds [20], [21], [22] and color of wastewater processes [23]. Effluents from this industry are highly colored. In general, lignin and its derivatives are responsible for that strong coloration [24]. Biological treatments, such as activated sludge process, remain the most suitable treatment for the degradable organic matter (measured as BOD5), but the ability of these methods for removing refractory compounds is negligible. For example, using an activated sludge process for the treatment of CTMP pulping effluent, a maximum decrease of $68 \%$ was reported (12.000 $\mathrm{mgL}^{-1}$ initial COD), and similar values were found for NSSC pulping effluent $(14,200 \mathrm{mgL} 1$ of initial COD) [25]. In the case of chemical pulps, decreases of $31 \%$ were reported by treating the effluent with activated sludge [26], whereas the treatment in a Upflow Anaerobic Sludge Blanke (UASB) reactor produced an average efficiency of COD removal of $80-86 \%$ without recirculation and of $75-78 \%$ with recirculation $\left(1.400 \mathrm{mgL}^{-1}\right.$ of initial COD) [27]. The final values of COD reported with the use of biologic treatment, indicate that the degree of degradation achieved is not sufficient to comply with the regulations [28]. It is therefore necessary to identify alternative methods that can degrade these compounds.

Advanced Oxidation Processes (AOP) can produce a total mineralization, transforming recalcitrant compounds into inorganic substances $\left(\mathrm{CO}_{2}\right.$ and $\left.\mathrm{H}_{2} \mathrm{O}_{2}\right)$, or partial mineralization, transforming them into more biodegradable substances. Therefore, three levels of degradation can be defined: [29]: (i) primary degradation, which causes a structural change in the compound, allowing it to be more easily removed by other processes (for example, biological treatment, adsorption, etc.), (ii) acceptable degradation, which involves the decomposition of the compounds, reducing their toxicity, (iii) final degradation, the last step comprising the mineralization of organic compound. AOP are powerful systems capable of transforming pollutants into harmless substances in a short reaction time and can be used to treat effluents from the chemical, petrochemical, textile, and other industries, and also from the pulp and paper mills [30], [31].

AOP exploit the high energy of hydroxyl radicals, which attack most of organic molecules: aromatic rings, polyphenols, halogenated compounds, resin acids, unsaturated fatty acids, compounds resulting from the decomposition process of organic nitrogen, or mutagenic compounds as TNT [32], [33], [34], [35], [36], [37], [38]. They have the ability to destroy dissolved organic contaminants, such as halogenated hydrocarbons (trichloroethane, trichlorethylene), aromatic compounds (benzene, toluene, ethylbenzene, xylene BTXE), volatile organic compounds (VOCs), pentachlorophenol (PCP), nitrophenols, detergents and pesticides, as well as inorganic contaminants such as cyanides, sulfides and nitrites [39], with a constant speed on the order of $106-109 \mathrm{M}^{-1} \mathrm{~s}^{-1}$ [40].

The high reactivity of these radicals and their low oxidation selectivity are useful attributes that made this process a promising technology for the treatment of effluents containing refractory organic compounds [41], [42]. The main strengths of the oxidative processes are that they do not transfer contaminants from one medium to another, as do other techniques such as flocculation or membranes, for example. The formation of sludge does not usually happen, 
and in some cases complete mineralization of refractory compounds occurs [43]. As negative aspects of these processes, the high investment and operating costs [a common feature to all processes and their main problem], and the generation of undesirable byproducts may be mentioned [44]. The combination of biological and chemical processes (each process affected by their individual parameters) may result in a more economical option to increase the treatability of refractory effluents, by increasing the $\mathrm{BOD}_{5} / \mathrm{COD}$ ratio and /or by the better utilization of the oxygen rate [45]. Therefore, chemical oxidation is affected by the amount of oxidizable organic compounds, the reaction rate between the oxidizing agents and the organic compounds, and by chemical conditions, such as $\mathrm{pH}$ and temperature, whereas the biological processes are affected mainly by the $\mathrm{pH}$, the presence of toxic substances, the redox potential and the oxygen available. For each treatment there is an optimal combination of conditions, which in turn can be organized in multiple ways. Therefore, changes in the input composition of the effluent are easily solved by changing the parameters in each stage, thereby allowing a wide range of possibilities and a flexible design of the process [29]. Chemical oxidation has been shown to be an efficient method to increase the treatability of effluents from the pulp and paper industries and to reduce their toxicity [46].

Oxidation is defined as the transfer of one or more electrons from an electron donor (reductant) to an electron acceptor (oxidant), which has a higher affinity for electrons. These electron transfers result in the chemical transformation of both the oxidant and the reductant, producing in some cases chemical species with an odd number of valence electrons. These species, known as radicals, tend to be highly unstable and hence highly reactive because one of their electrons is unpaired. Oxidation reactions that produce radicals tend to be followed by additional oxidation reactions between the radical oxidants and other reactants (both organic and inorganic) until thermodynamically stable oxidation products are formed. The ability of an oxidant to initiate chemical reactions is measured in terms of its oxidation potential. The most powerful oxidants are fluorine, hydroxyl radicals $(\mathrm{HO} \bullet)$, ozone, and chlorine, with oxidation potentials of $2.85,2.70,2.07$ and 1.49 electron volts, respectively [47]. Several technologies such as Fenton, photo-Fenton, ozonation, photocatalysis, etc. are included in the group of the AOP and the main difference between them is the source of radical production [48]

For the effective oxidation of refractory organic compounds, hydroxyl radicals should be generated continuously in situ through photochemical reactions due to its chemical instability. Generation of $\mathrm{HO}$ - is commonly accelerated by combining some oxidizing agents such as ozone $\left(\mathrm{O}_{3}\right)$, hydrogen peroxide $\left(\mathrm{H}_{2} \mathrm{O}_{2}\right)$, UV radiation, and ferrous and ferric salts $\left(\mathrm{Fe}^{+2}\right.$ and $\left.\mathrm{Fe}^{+3}\right)$ [49], and also by radiation sources such as ultrasound, visible, solar and thermal energy. In more advanced processes, the radicals can be generated by gamma radiation, microwave or electron beams $[50]$. By adjusting the reaction conditions, the $\mathrm{HO} \cdot$ radicals with a significant oxidation potential up to $2.8 \mathrm{~V}$, can attack a wide variety of contaminants. Among these treatments, UV radiation plus hydrogen peroxide $\left(\mathrm{UV} / \mathrm{H}_{2} \mathrm{O}_{2}\right)$, Fenton's reagent $\left(\mathrm{H}_{2} \mathrm{O}_{2} / \mathrm{Fe}^{+2}\right)$, photo-Fenton $\left(\mathrm{UV} / \mathrm{H}_{2} \mathrm{O}_{2} / \mathrm{Fe}^{+2}\right)$, and ozone combinations $\left(\mathrm{O}_{3} / \mathrm{UV} \mathrm{O} \mathrm{O}_{3} / \mathrm{H}_{2} \mathrm{O}_{2}\right)$ are considered to be effective for the oxidation of effluents from the pulp and paper industries [51], [52], [53], [54], [55], [56].

Some examples in which AOP were used to treat pulp and paper effluents are shown in Table 2, whereas the yield achieved in each case is represented in Figure 1. Yields of the processes are represented by the percentage of COD reduction ((final COD/initial COD)*100).

Table 2. Examples of AOP applied to the oxidation of effluents from pulp and paper industries

\begin{tabular}{|c|c|c|c|}
\hline Effluent & $\begin{array}{c}\text { Initial COD } \\
{\left[\mathrm{mgL}^{-1}\right]}\end{array}$ & AOP & Reference \\
\hline a. Recycled paper mill & 2319 & $\mathrm{O}_{3}$ & {$[57]$} \\
\hline b. Kraft pulp mill & 1749 & $\mathrm{O}_{3}$ & {$[57]$} \\
\hline c. Resin acids mixture I & 1880 & $\mathrm{O}_{3}$ & {$[58]$} \\
\hline d. Resin acids mixture II & 1542 & $\mathrm{O}_{3}$ & {$[58]$} \\
\hline d. Resin acids mixture III & 1918 & $\mathrm{O}_{3}$ & {$[58]$} \\
\hline e. Resin acids mixture I & 1880 & UV & {$[58]$} \\
\hline f. Resin acids mixture II & 1542 & UV & {$[58]$} \\
\hline g. Resin acids mixture III & 1918 & $\mathrm{O}_{3}+\mathrm{UV}+\mathrm{H}_{2} \mathrm{O}_{2}$ & {$[58]$} \\
\hline h. Black liquor & 628 & Fenton & {$[59]$} \\
\hline i. Kraft bleaching plant* & 537 & Fenton & {$[60]$} \\
\hline j. Bleaching plant & 1150 & $\mathrm{UV} / \mathrm{FeIII} / \mathrm{H}_{2} \mathrm{O}_{2}$ & {$[36]$} \\
\hline k. Kraft bleaching plant * & 441 & Fenton & {$[61]$} \\
\hline 1. Kraft bleaching plant* & 441 & UV/Fenton & {$[61]$} \\
\hline m. Kraft pulp mill & 441 & $\mathrm{UV} / \mathrm{O}_{3}$ & {$[62]$} \\
\hline n. Kraft pulp mill & 441 & $\mathrm{O}_{3}$ & {$[62]$} \\
\hline o. Kraft pulp mill & 441 & UV/Fenton & {$[62]$} \\
\hline
\end{tabular}

* Corresponds to initial total organic carbon (TOC)

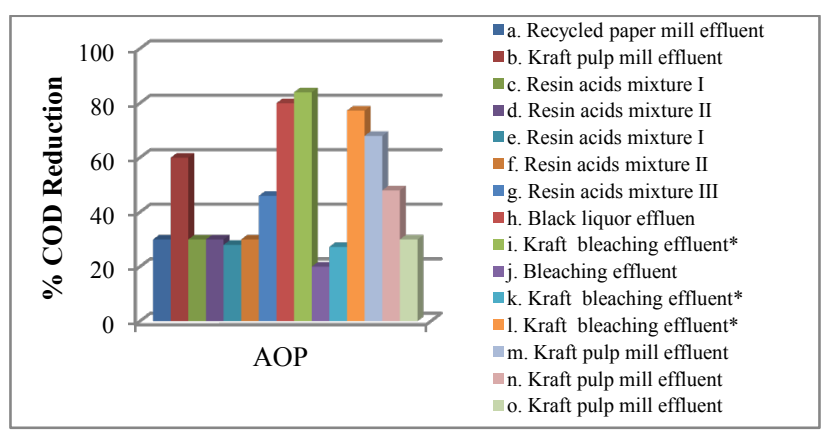

Figure 1. COD reduction (as percentage) in cases presented in table 2

\subsection{Advanced Oxidation by Ozone}

Ozone is an oxidizing gas which reacts with inorganic and organic compounds, directly or indirectly, through the formation of hydroxyl radicals. Ozone oxidizes preferentially electron-rich molecules containing carbon-carbon double bonds and aromatic alcohols, but not those have single bonds [58]. It is poorly soluble in water (12 $\mathrm{mg} \mathrm{dm}{ }^{-3}, 25^{\circ} \mathrm{C}$ ), but once in contact with water, it becomes highly unstable and rapidly decomposes through a complex series of reactions [59], in accordance with the mechanism of hydroxide ions $\left(\mathrm{HO}^{-}\right)$: 


$$
\begin{aligned}
\mathrm{O}_{3}+\mathrm{HO}^{-} & \rightarrow \mathrm{HO}_{2}^{-}+\mathrm{O}_{2} \\
\mathrm{HO}_{2}^{-}+\mathrm{O}_{3} \rightarrow \mathrm{O}_{3}^{-} \bullet+\mathrm{HO}_{2} \bullet & \\
\mathrm{HO}_{2} \bullet & \rightarrow \mathrm{O}_{2} \bullet+\mathrm{H}^{+} \\
\mathrm{O}_{3}+\mathrm{O}_{2} \bullet & \rightarrow \mathrm{O}_{3}^{-} \bullet+\mathrm{O}_{2} \\
\mathrm{O}_{3}^{-} \bullet+\mathrm{H}^{+} & \rightarrow \mathrm{HO}_{3} \bullet \\
\mathrm{HO}_{3} \bullet & \rightarrow \mathrm{HO} \bullet+\mathrm{O}_{2} \\
\mathrm{O}_{3}+\mathrm{HO} \bullet & \rightarrow \mathrm{O}_{2}+\mathrm{HO}_{2} \bullet
\end{aligned}
$$

The chain reaction is sustained by the formation of the $\mathrm{HO}_{2} \bullet$ radical, which can then initiate further reactions. The hydroxyl radical $(\mathrm{HO} \bullet)$ is the most important species formed during the ozone decomposition. Therefore, depending on the behavior of the ozone in the aqueous environment, the selectivity of ozonation may be high (direct reaction) or low (indirect reaction) [65].

The main factors affecting ozonation performance are: $\mathrm{pH}$, the nature and concentration of oxidisable organic compounds, ozone dose, competition between the target compound and biodegradable by-products, the presence of oxidant scavengers, and the efficiency of ozone mass transfer [66]. Ozone is effective to decolorize effluents, and can convert wastewater biorefractory compounds into biodegradable ones [67]. Ozone treatment itself seems to have little impact on the reduction of the concentration of total organic carbon (TOC), but a rapid decrease in UV 254 absorbance was observed during the treatment. Although it did not mineralize the organic matter present in the effluent, it altered its chemical structure. Prolonging the duration of the ozone treatment beyond $5 \mathrm{~min}$ did not produce aditional benefits. The oxidation products are suspected to be relatively non-reactive to ozone [68]. Many catalysts are used in combination with ozone to enhance the oxidation process. Ultraviolet light and ultrasonic have been used to produce further hydroxyl radicals, thus improving the degradation effect [69].

The ozone dosage played an important role in discoloration. The increase of the ozone dosage in 10-fold produces a 19-fold increase of the discoloration rate. When the liquid is saturated, an excess of ozone dosage do not enhance the discoloration, since ozone solubility is constant at a certain temperature. If ozone concentration is higher than the optimum dose, the amount of $\mathrm{HO} \cdot$ radicals and ozone in solution are virtually invariant. When the initial concentration of organic matter is high, more $\mathrm{HO} \bullet$ radicals are consumed, so the increase of ozone concentration can have a positive effect in this case [70].

Ozonation best performance occurs at alkaline $\mathrm{pH}$, and is due to the reaction of almost all organic and inorganic compounds with the molecular ozone and the oxygen radicals, including the hydroxyl radical. These phenomena are attributed to the ability of $\mathrm{O}_{3}$ to initiate hydroxyl radical formation at high $\mathrm{pH}$. These hydroxyl radicals have an oxidation potential $\left(\mathrm{E}^{\circ}=2.80\right)$ higher than $\mathrm{O}_{3}\left(\mathrm{E}^{\circ}=2.07\right)$ in the direct reaction under acidic conditions [71]. Conversely, under acidic conditions, the selective reaction of ozonation involves only the ozone with unsaturated organic compounds. Removing color and COD has not been different in a $\mathrm{pH}$ range of 4.5 to 11 , but the oxidation of phenolic compounds has been favored at $\mathrm{pH}$ higher than 9 [26]. With similar reaction conditions $(\mathrm{pH}=10-12)$ the efficiency of the ozone oxidation of phenolic compounds in a liquor corresponding to the first alkaline extraction of a Kraft industry has been proved [72]. Phenolic compounds have been shown to promote $\mathrm{O}_{3}$ decomposition and increase radical $\mathrm{HO} \bullet$ exposure [73].

The action of ozone, which is often limited to a partial oxidation of the organic matter, seems to be a viable technique for the treatment of the papermaker's effluents, as it is able to accomplish the degradation of lignin products and to reduce the organic load. Therefore, ozonation may be used as a first step in the treatment of effluents from the pulp and paper industry, followed by a treatment in an aerobic biological reactor [74] [75]. The combination of ozonation with biological treatment reduces biological regrowth potential, because biological treatment can remove biodegradable organic matter selectively. Ozonation transforms large molecules into smaller ones, thus increasing the biodegradability of the organic matter [76].

Numerous examples of treatment of effluents from paper mills with ozone show that the produced oxidation is able to decrease the quantity of organochlorine organic compounds, extractives, lignin derivatives, resin and fatty acids, color and toxicity, but it cannot reach high values of oxidation [77]. Ozonation combined with biological treatment is an effective method for treating effluent from several pulping processes [78].

The destruction of lipophilic extracts with an increase of biodegradability represented by the BOD/COD ratio [79], and a decrease of $90 \%$ of the extractives and $50 \%$ of the COD [80] have been reported for two different TMP effluents. A reduction of $12 \%$ of TOC, $70 \%$ of total phenols, and a $35 \%$ in color after 60 minutes of ozonation have been informed for an industry that produces bleached Kraft pulp [81]. Ozonation of wastewater from a similar industry with doses of 0.7 to $0.8 \mathrm{mgL}^{-1}$ for $120 \mathrm{~min}$ resulted in a COD removal of about $21 \%( \pm 5 \%)$. By integrating ozonation with a biological treatment, a reduction of $50 \%$ TOC has been obtained, i.e. $30 \%$ higher than the performance of each individual treatment [82]. It has been found that the use of ozone (dose: $50-250 \mathrm{mgL}^{-1}$ ) as a pretreatment of a biological reactor is effective for the treatment of a bleached Kraft pulp effluent, as it increase the effluent biodegradability, checked by increasing BOD along with the reduction in COD (reductions close to $11 \%$ ). With the use of ozone as a postreatment, the reduction percentages were much lower [83].

\subsection{Advanced Oxidation by Hydrogen Peroxide}

In the case of hydrogen peroxide, the reaction between the generated $\mathrm{HO} \cdot$ and many organic contaminants occurs rapidly. However, although the reaction itself produces no direct mineralization of these pollutants, it produces the oxidation of organic products, which can in turn react with 
the $\mathrm{HO} \cdot$ radical. The use of this agent has emerged as a viable alternative among other advanced oxidation processes, because it is a non-toxic reagent that does not form any harmful by-product, improves the efficiency and reduces the critical conditions of the oxidation reaction [84]. For a given concentration of $\mathrm{H}_{2} \mathrm{O}_{2}$ and $\mathrm{pH}$, hydroxyl radical production mainly depends on catalyst concentration and reaction temperature. Once the radical is formed, it can react with the unreacted $\mathrm{H}_{2} \mathrm{O}_{2}$ or the organic matter, resulting in oxidized species.

$$
\begin{gathered}
\mathrm{H}_{2} \mathrm{O}_{2}+\mathrm{HO} \bullet \rightarrow \mathrm{HO}_{2} \bullet+\mathrm{H}_{2} \mathrm{O} \\
\mathrm{HO}_{2} \bullet+\mathrm{HO} \bullet \rightarrow \mathrm{O}_{2}+\mathrm{H}_{2} \mathrm{O}
\end{gathered}
$$

The first reaction is favored when the effluent contains high levels of organic matter, and leads to a high degree of mineralization (desired reaction.) The second is favored when the $\mathrm{H}_{2} \mathrm{O}_{2}$ is present in large amounts [relative to the organic matter content] or the load of catalyst is low. This reaction affects the efficiency of the overall degradation and acts as a radical scavenger, resulting in a significant increase in operating costs [85], and inhibitory effects on degradation of the compounds [86]. Since hydrogen peroxide itself is not able to oxidize the dissolved matter, radicals should be generated from the direct reaction of another oxidant [such as ozone] and the ionic form of hydrogen peroxide, which is the initiation stage of a radical mechanism [87]. The catalyzed reaction of ozone with hydroxyl ion must be considered as a second step of the radical initiation mechanism, leading to the formation of hydroxyl radicals. The rate of initiation of the reaction of radical generation becomes more important at high $\mathrm{pH}$ [88]. The combination of these two oxidizing agents is also beneficial in the treatment of compounds that show little or no reactivity towards the direct attack of the ozone molecule [89].

\subsection{Advanced Oxidation by catalyzed $\mathrm{H}_{2} \mathrm{O}_{2}$}

Early studies on advanced oxidation processes with $\mathrm{H}_{2} \mathrm{O}_{2}$ were carried out using metal salts (mostly iron) as homogeneous catalysts in reactions known as Fenton-type reactions. These systems have been successfully applied to the oxidation of various compounds, including phenol and its derivatives. However, it is generally preferred the use of solid catalysts which can be recovered by a simple separation operation and reused in the treatment process. For this reason, variants of catalytic systems that can work with the active ions in a solid support are under study [90]. Among the advanced oxidation processes, the Fenton reaction has been proved to be ease to handle and more effective in terms of removal rate. The main organic pollutants "target" of the Fenton's reagent are soluble substances, aromatic nucleophilic compounds [91], and polyphenols such as lignin [92]. Radicals are formed by the reaction:

$$
\mathrm{H}_{2} \mathrm{O}_{2}+\mathrm{Fe}[\mathrm{II}] \rightarrow \mathrm{Fe}[\mathrm{III}]+\mathrm{HO}^{-}+\mathrm{HO} \bullet
$$

The reaction mechanism of this reagent has not been completely explained due to the variety of complex compounds and intermediates which are formed and their subsequent reactions. During the reactions with the $\mathrm{H}_{2} \mathrm{O}_{2}$ solution and of $\mathrm{Fe}(\mathrm{II})$ salts, the organic compounds are oxidized with a radical chain mechanism [93], where the hydroxyl radicals are capable of attacking rapidly to organic substrates. The main stages of the process are [94]:

$$
\begin{aligned}
& \mathrm{RH}+\mathrm{HO} \bullet \rightarrow \mathrm{R} \bullet+\mathrm{H}_{2} \mathrm{O} \\
& \mathrm{R} \bullet+\mathrm{Fe}(\mathrm{III}) \rightarrow \mathrm{R}^{+}+\mathrm{Fe}(\mathrm{II}) \\
& \mathrm{R}^{+}+\mathrm{H}_{2} \mathrm{O} \rightarrow \mathrm{ROH}+\mathrm{H}^{+}
\end{aligned}
$$

Numerous competing reactions, involving $\mathrm{Fe}(\mathrm{II}), \mathrm{Fe}(\mathrm{III})$, $\mathrm{H}_{2} \mathrm{O}_{2}$, hydroxyl radicals, and hydroperoxyl radicals $\left(\mathrm{HO}_{2} \bullet\right)$ derived from the substrate can occur. Hydroxyl radicals can be swept by reaction with $\mathrm{Fe}(\mathrm{II})$ or hydrogen peroxide.

$$
\begin{aligned}
& \mathrm{HO} \bullet+\mathrm{Fe}(\mathrm{II}) \rightarrow \mathrm{HO}^{-}+\mathrm{Fe}(\mathrm{III}) \\
& \mathrm{HO} \cdot+\mathrm{H}_{2} \mathrm{O}_{2} \rightarrow \mathrm{H}_{2} \mathrm{O}+\mathrm{HO}_{2} \cdot
\end{aligned}
$$

The Fe(III) formed through the mentioned reactions can react with $\mathrm{H}_{2} \mathrm{O}_{2}$, according to a radical mechanism, consisting of hydroxyl and hydroperoxyl radicals, with the regeneration of $\mathrm{Fe}(\mathrm{II})$.

$$
\begin{gathered}
\mathrm{Fe}(\mathrm{III})+\mathrm{H}_{2} \mathrm{O}_{2} \rightarrow \mathrm{Fe}-\mathrm{OOH}^{2+}+\mathrm{H}^{+} \\
\mathrm{Fe}-\mathrm{OOH}^{2+} \rightarrow \mathrm{HO}_{2} \bullet+\mathrm{Fe}(\mathrm{II}) \\
\mathrm{Fe}(\mathrm{II})+\mathrm{HO}_{2} \bullet \rightarrow \mathrm{Fe}(\mathrm{III})+\mathrm{HO}_{2}^{-} \\
\mathrm{Fe}(\mathrm{III})+\mathrm{HO}_{2} \bullet \rightarrow \mathrm{Fe}(\mathrm{II})+\mathrm{H}^{+}+\mathrm{O}_{2}
\end{gathered}
$$

The rapid decomposition of $\mathrm{H}_{2} \mathrm{O}_{2}$ is attributed to the immediate reduction of $\mathrm{Fe}$ (III) to $\mathrm{Fe}$ (II) after each cycle of the Fenton reaction. The efficiency of Fenton process depends on the generation rate and the concentration of oxidizing agents formed during Fenton reaction. Operational parameters that directly affect the efficiency of the process are: the source of iron catalyst (e.g. ferrous or ferric salt), iron and hydrogen peroxide concentrations, their ratio, $\mathrm{pH}$, temperature and treatment time [95].

Several studies indicate that high efficiencies of consumption and conversion could be obtained with an oxidant dosage strategy that minimizes the peroxide decomposition into non-oxidizing (parasitic) species [96], [97]. A decrease in $\mathrm{pH}$ values due to the formation of acidic intermediates was verified. The increase of the initial $\mathrm{H}_{2} \mathrm{O}_{2}$ concentration first enhances the oxidation process resulting in an increase of TOC removal until it reaches a maximum, and thereafter, higher hydrogen peroxide concentrations inhibit the degradation of organic compounds in wastewater. It is therefore very important to optimize the applied $\mathrm{H}_{2} \mathrm{O}_{2}$ dose in order to maximize the oxidation reaction [98].

Lignocellulosic materials may contain reducing agents for $\mathrm{Fe}[\mathrm{III}]$ in their structure, such as extractives (phenolic compounds or terpenes) or cell wall polymers (lignin), which contribute to the generation of hydroxyl radicals [99].

The main advantage of the Fenton process is that the reagents are safe to handle and environmentally benign. It does not require highly complicated devices or pressurized systems for the oxidation process, making it technologically a viable for direct application on any scale (laboratory industry), [100]. It can also be used as a pretreatment of the 
biological stage in order to increase the biodegradability of recalcitrant compounds, reducing the toxicity of the wastewater [101], [102], [103] and for the elimination of the organochlorine compounds and polyphenols contained in effluents from some bleaching processes [104], [105]. Complete oxidation of organic substances by the Fenton's reagent, which lead to the formation of carbon dioxide, is generally inconvenient due to a high consumption of hydrogen peroxide [106]. The potential application of Fenton technology for the treatment of highly polluted industrial effluents requires to achieve high efficiencies of $\mathrm{H}_{2} \mathrm{O}_{2}$ consumption, since this is the critical component of the operating costs. High temperatures increase TOC and COD removal, since $\mathrm{H}_{2} \mathrm{O}_{2}$ consumption is more efficient in these conditions. For example, COD removal was $92 \%$ at $90^{\circ} \mathrm{C}$ compared to $67 \%$ at $50^{\circ} \mathrm{C}$ [107].

The optimum $\mathrm{pH}$ in Fenton reactions for COD and TOC removal seems to be 3 in most studies. At higher $\mathrm{pH}$ values, free $\mathrm{Fe}^{2+}$ ions concentration decreases due to the formation of ferrous complexes and the precipitation of ferric hydroxides. The oxidation potential of hydroxyl radicals also decreases when $\mathrm{pH}$ increases. Hydrogen peroxide stability is high at $\mathrm{pH} 3-4$, but it decomposes when $\mathrm{pH}$ increases [108]. Besides the iron salts, other transition metals having at least two oxidation states, such as copper, ruthenium, cerium and manganese, can also promote the generation of hydroxyl radicals from $\mathrm{H}_{2} \mathrm{O}_{2}$. However, due to economic and environmental constraints, the iron salts are generally preferred for the process [109].

Elements with multiple redox states (like chromium, cerium, copper, cobalt, manganese, and ruthenium) all directly decompose $\mathrm{H}_{2} \mathrm{O}_{2}$ into $\mathrm{HO} \cdot$ through conventional Fenton-like pathways. These systems work efficiently even at neutral $\mathrm{pH}$. The $\mathrm{H}_{2} \mathrm{O}_{2}$ activation mechanism is very specific to the nature of the catalyst and critically depends on its composition. To achieve an efficient electron transfer to $\mathrm{H}_{2} \mathrm{O}_{2}$, the ideal Fenton catalyst should exhibit multiple oxidation states because the catalytically-active species with a specific oxidation state can be easily regenerated from an inactive form through a simple redox cycle. To achieve this objective, both active and inactive redox states should be stable over a wide $\mathrm{pH}$ range to prevent the precipitation of the catalytic species. In terms of its reactivity towards $\mathrm{H}_{2} \mathrm{O}_{2}$, redox properties of copper are strikingly similar to those of iron. Both the monovalent $\left(\mathrm{Cu}^{+}\right)$and divalent $\left(\mathrm{Cu}^{2+}\right)$ oxidation states react easily with $\mathrm{H}_{2} \mathrm{O}_{2}$. This Fenton-like system should work over a broader $\mathrm{pH}$ range, compared to the traditional Fenton system working only in acidic conditions. All copper based Fenton catalysts efficiently generate $\mathrm{HO} \cdot$ for the oxidation of various organic pollutants in near-neutral or neutral aqueous solutions. Additionally, $\mathrm{Cu}^{2+}$ complexes with organic degradation intermediates (organic acids) are easily decomposed by $\mathrm{HO} \cdot$, whereas the corresponding $\mathrm{Fe}^{3+}$ complexes are highly stable [110].

Combinations of an electrochemical process with the Fenton process, named the electro-Fenton method, was developed to enhance the oxidation of organic compounds
[111], in which the reactions between hydroxyl radicals and the organic compounds are easily carried out [112]. This method is divided into four categories. In type 1, hydrogen peroxide and ferrous ions are electro generated using a sacrificial anode and a bubbling oxygen cathode.

In type 2, a sacrificial anode is used as a source of ferrous ions and hydrogen peroxide is externally added. In type 3, ferrous ions are externally added and hydrogen peroxide is generated using a bubbling oxygen cathode. In the type 4 [the most used one], Fenton's reagent is used to produce hydroxyl radicals in an electrolytic cell and ferrous ion is regenerated by the reduction of ferric ions at the cathode [113]. Using this method, COD reduction up to $96 \%$ in a Kraft pulp mill effluent [initial COD: $1669.7 \mathrm{mgL}^{-1}$ ] was achieved [114].

\subsection{Advanced Oxidation by UV Radiation}

UV radiation alone is popular for water disinfection, but does not have any applicability in the treatment of effluents. $\mathrm{UV} / \mathrm{H}_{2} \mathrm{O}_{2}, \mathrm{UV} / \mathrm{O}_{3}$, and their combinations are suitable for treating the organic components of the effluents. An optimization procedure applicable to $\mathrm{UV} / \mathrm{O}_{3}$ or $\mathrm{UV} / \mathrm{H}_{2} \mathrm{O}_{2}$ may be extended to $\mathrm{UV} / \mathrm{O}_{3} / \mathrm{H}_{2} \mathrm{O}_{2}$. Combinations $\mathrm{UV} / \mathrm{O}_{3}$ and $\mathrm{UV} / \mathrm{H}_{2} \mathrm{O}_{2}$ processes are qualitatively similar, but show slight quantitative differences in the optimization. Since ozone is a gas, the solubility should be taken into consideration and the influence of pressure on solubility cannot be ignored. Furthermore, $\mathrm{H}_{2} \mathrm{O}_{2}$ is commonly available as a $30 \%$ solution. As it has an unlimited solubility in water, the system pressure is not a variable, providing some simplification in the analysis and experimentation [115]. $\mathrm{UV} / \mathrm{H}_{2} \mathrm{O}_{2}$ treatment is based on the formation of radicals $\mathrm{HO} \cdot$ by photolysis of the hydrogen peroxide:

$$
\mathrm{H}_{2} \mathrm{O}_{2}+\mathrm{h} v \rightarrow 2 \mathrm{HO} \cdot
$$

$\mathrm{H}_{2} \mathrm{O}_{2}$ molar absorptivity at $253.7 \mathrm{~nm}$ is low, about $20 \mathrm{M}^{-1}$ $\mathrm{cm}^{-1}$ and the $\mathrm{HO} \cdot$ are formed by the absorption of an incident photon. At this wavelength, the speed of photolysis of aqueous hydrogen peroxide is about 50 times slower than that of ozone. $\mathrm{UV} / \mathrm{H}_{2} \mathrm{O}_{2}$ technique requires a relatively higher dose of $\mathrm{H}_{2} \mathrm{O}_{2}$ and / or longer exposure to UV rays than, for example, the $\mathrm{UV} / \mathrm{O}_{3}$ process. Furthermore, it has been found that the speed of photolysis of hydrogen peroxide is $\mathrm{pH}$ dependent and increases in alkaline conditions, because of the formation of $\mathrm{HO}_{2}$ - anions, which show a molar absorptivity of $240 \mathrm{M}^{-1} \mathrm{~cm}^{-1}$ at $253.7 \mathrm{~nm}$, which is higher than the hydrogen peroxide, by the reaction [116]:

$$
\mathrm{HO}_{2}^{-}+\mathrm{hv} \rightarrow \mathrm{HO} \bullet+\mathrm{O}^{-}
$$

These combined treatments were tested under various conditions on an effluent from a bleaching process, characterized by its high content of chelating agents. Ozone alone was not effective, however, by using $\mathrm{UV} / \mathrm{O}_{3}$ treatment reductions of $95 \%$ and $98 \%$ in COD and chelating agents respectively were achieved [117]. The oxidation of aromatic compounds such as lignin and phenolic extractives from lignocellulosic materials and TOC reduction, have been 
found to be more efficient at $\mathrm{pH} \geq 7$ with $\mathrm{UV} / \mathrm{H}_{2} \mathrm{O}_{2}$ treatment [118].

When using the $\mathrm{UV} / \mathrm{H}_{2} \mathrm{O}_{2}$ technique is important to note that the synergistic effect between the UV radiation and hydrogen peroxide is beneficial only with contaminants that require a relatively aggressive oxidation conditions (high activation energies). There is a concentration of peroxide beyond which the presence of hydrogen peroxide is detrimental to the oxidation reaction, so the optimal peroxide concentration needs to be selected. The presence of compounds that strongly absorb incident UV light [for example, humic acid] is another factor that must be considered. If these compounds are present in the effluent stream, a higher dose of hydrogen peroxide to achieve the synergistic effect is required [119].

In the treatment of an effluent from a bleaching process (chlorination and alkali extraction stages), the color removal was more influenced by the $\mathrm{pH}$ than by UV. This is explained by the increased presence of easily degradable chromophores compounds at basic $\mathrm{pH}$. It was verified that the discoloration constant depends on $\mathrm{pH}$ rise, contributing favorably to increase the reaction rate [120]. When treating a phenol solution ( 40 to $500 \mathrm{mgL}^{-1}$ ), almost $25 \%$ of phenol was oxidized in $1.5 \mathrm{~h}$, and over $45 \%$ of the degradation took place during a period of $4 \mathrm{~h}$ due to direct UV photolysis, or by the attack of the hydroxyl radicals.

By using a $\mathrm{H}_{2} \mathrm{O}_{2}$ /phenol molar ratio of 125 , more than $95 \%$ of the phenol was oxidized in $40 \mathrm{~min}$. At higher $\mathrm{H}_{2} \mathrm{O}_{2}$ /phenol ratios ( $>300$ ), the oxidative process is adversely affected even though the rate of free radicals production is higher. $\mathrm{H}_{2} \mathrm{O}_{2} / \mathrm{UV}$ combinations significantly enhanced the degradation of phenol compared to direct photolysis [121].

$\mathrm{O}_{3} / \mathrm{UV}$ process is effective for oxidation and destruction of toxic and water-refractory organic compounds. It consists basically of an aqueous system saturated with ozone, which is irradiated with UV light at $253.7 \mathrm{~nm}$. The extinction coefficient of ozone at $253.7 \mathrm{~nm}$ is $3300 \mathrm{~m}^{-1} \mathrm{~cm}^{-1}$, much higher than that of hydrogen peroxide and its decomposition rate is about 1000 times greater than that of the same reagent. $\mathrm{O}_{3} / \mathrm{UV}$ combination improves the efficiency of the individual processes. The synergistic effects of the combined treatments increase by increasing $\mathrm{pH}$ to basic levels. This is attributed to the catalytic effect of HO- ion on the ozonation initiation [116].

Irradiation of ozone in water produces $\mathrm{H}_{2} \mathrm{O}_{2}$ quantitatively. Hydrogen peroxide thus generated is in turn photolyzed, generating radicals $\mathrm{HO} \bullet$ and reacts with the excess of ozone generating radicals which contribute to oxidation, according to equation [122]:

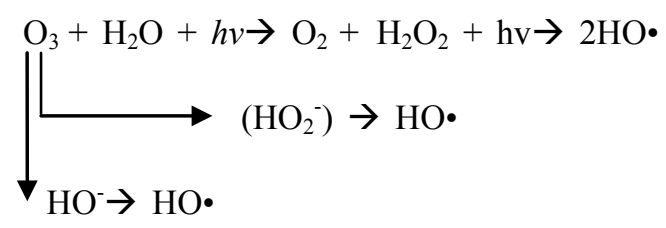

Accordingly, the conditions to be considered for $\mathrm{O}_{3} / \mathrm{UV}$ processes can be summarized as [119]: high partial pressures and continuous bubbling of ozone; low initial concentration of contaminants (in general, the effluent requires dilution); temperature optimization taking into account the increase in the rate of degradation and the low solubility of ozone at high temperatures; neutral or slightly alkaline $\mathrm{pH}$ (range 7-8); minimum presence of radical scavengers because they inhibit the process of degradation. These combined treatments which involve photodegradation are important for removing aromatic hydrocarbons and chlorinated phenolic compounds present in some bleaching effluents of kraft pulp [123]. Bleaching processes using chlorine generate bioaccumulative and carcinogenic substances (such as chlorophenols), which are difficult to remove with a biological treatment or by oxidative treatments applied individually [124].

The efficiency of degradation of Fenton process is also accelerated by irradiation with UV light [125]. It is expected also a improvement of the efficiency in the oxidation reaction, because in this case two different pathways contribute to the generation of free radicals (UV radiation and iron salts) and, therefore, its concentration should be high [126]. Fenton and photo Fenton efficiencies have been monitored in the treatment of an effluent from a TMP pulping process. The increase in discoloration produced by the last one was attributed to the increased radical attack to the double bonds of the lignin in the effluent, responsible for its color [23]. Color removal was also verified when treating bleach effluents from unbleached Kraft pulping processes [127]. Some stages in the pulp and paper mill require recirculating water of high quality. In these cases, reverse osmosis systems are implemented as the final step of the different treatments applied for the reduction of recalcitrant toxic compounds. The photo-Fenton system has been proved to be a viable alternative in these cases requiring strict processing conditions [128]. Fenton oxidation has also been evaluated for oxidation of chelants, reaching reductions of about $90 \%$. The oxidation rate was increased by photo-Fenton treatment [129]. This oxidation treatment is also highly efficient when applied to the effluents of a wastepaper plant (TOC concentration: $332 \mathrm{mgL}^{-1}$ and COD: $\left.1286 \mathrm{mgL}^{-1}\right)$. Generally, over $90 \%$ of TOC can be removed with optimized conditions, especially at temperatures about $50^{\circ} \mathrm{C}$. Because the temperature of the effluent is normally between 40 and $50^{\circ} \mathrm{C}$, no energy input is required. Therefore, efficient TOC removal is highly possible under the usual operation conditions [53].

When testing various oxidizing systems on a solution of phenol $\left(93-105 \mathrm{mgL}^{-1}\right)$, it was found that no combination of ozone $\left(\mathrm{O}_{3} / \mathrm{H}_{2} \mathrm{O}_{2}, \mathrm{O}_{3} / \mathrm{UV}\right.$ and $\left.\mathrm{O}_{3} / \mathrm{UV} / \mathrm{H}_{2} \mathrm{O}_{2}\right)$ enhanced the rate of degradation with respect to the use of ozone alone. Concerning peroxide treatment, the degradation rate of the $\mathrm{UV} / \mathrm{H}_{2} \mathrm{O}_{2}$ process was almost five-fold higher than with $\mathrm{UV}$. Fenton's reagent resulted in a degradation 40 -fold faster than the UV process. The highest percentages of reduction achieved were, $\mathrm{O}_{3}: 100 \% ; \mathrm{O}_{3} / \mathrm{H}_{2} \mathrm{O}_{2}: 92.5 \% \mathrm{UV}: 24.2 \%$; $\mathrm{UV} / \mathrm{H}_{2} \mathrm{O}_{2}: 90.6 \% ; \mathrm{O}_{3} / \mathrm{UV} / \mathrm{H}_{2} \mathrm{O}_{2}: 99.4 \% \mathrm{Fe}$ (II) $/ \mathrm{H}_{2} \mathrm{O}_{2}: 100 \%$ [130]. 
Various oxidative systems have been evaluated on different streams of wastewaters from pulp and paper mills. Applying different iron doses $\left(1.3,20\right.$, and $\left.50 \mathrm{mgL}^{-1}\right)$ in the Fenton's reagent on an outgoing effluent from a biological treatment (initial COD: 898,9 $\mathrm{mgL}^{-1}$ ), COD removal achieved was 4,18 , and $36 \%$, respectively. This low rate of degradation observed was attributed to the poor regeneration of ferrous ions (reduction of $\mathrm{Fe}$ (III) to $\mathrm{Fe}$ (II)) in the absence of UV light. On the contrary, when photo-Fenton was applied with 5 and $10 \mathrm{mgL}^{-1}$ of $\mathrm{Fe}(\mathrm{II}), \mathrm{COD}$ removal rates exceeded $90 \%$ [131]. The use of hydrogen peroxide alone resulted in too low removal values, also the UV treatment was ineffective by itself, producing unacceptably low color and TOC reductions (initial TOC: $110 \mathrm{mgL}^{-1}$ ), $\mathrm{UV} / \mathrm{H}_{2} \mathrm{O}_{2}$ treatment performance was also unsatisfactory and the same results were verified in the treatment with ozone of organochlorine compounds. Both, Fenton or photo-Fenton treatments can be used for effective removal of color, organochlorine compounds and TOC of those wastewaters, reaching reductions of about $80 \%$ in all parameters. However, the photo-Fenton treatment seems to be more advantageous because requires much less time to react and smaller reactor volumes, compared to Fenton treatment [51].

The degradation of the organic compounds in the bleaching effluents from a Kraft pulp mill has been successfully carried out by applying photo-Fenton and Fenton treatments. Temperature is a key parameter that significantly increases reaction rates whereas UV irradiation improves TOC removal. At high temperature the system has similar reaction rates in both, Fenton and photo-Fenton. In all experiments, the color of the samples was reduced over $90 \%$ at the end of the reaction [61].

The effect of the initial concentration of hydrogen peroxide in $\mathrm{UV} / \mathrm{H}_{2} \mathrm{O}_{2}$, Fenton and Photo-Fenton in the treatment of the effluent from a recycled cardboard mill (COD: $10300 \mathrm{mgL}^{-1}$ ) has been reported. Photo-Fenton treatment produced the greatest reduction in $\mathrm{COD}(76 \%)$ compared with $\mathrm{UV} / \mathrm{H}_{2} \mathrm{O}_{2}$ and Fenton, in 45 minutes [132]. With the same purpose, a papermaking effluent with a COD of $950 \mathrm{mgL}^{-1}$ was treated by the Fenton method, obtaining color and COD reductions of $95 \%$ and $50 \%$ respectively [133].

\section{Efficiency and Cost}

In all AOP processes, the hydroxyl radical is the main oxidizing agent [134], no contaminants are transferred from one phase to the other, the production of hazardous sludge is reduced [135], and the doses of $\mathrm{H}_{2} \mathrm{O}_{2}$ are critical. By increasing $\mathrm{H}_{2} \mathrm{O}_{2}$ concentration, hydroxyl radicals are more available for the oxidation of pollutants and the efficiency of removal of recalcitrant compounds also increases. However, when $\mathrm{H}_{2} \mathrm{O}_{2}$ exceeds a certain level, scavenger compounds are generated in the system, the sweep occurs and the efficiency of oxidation accordingly decreases. The amount of peroxide considered optimum depends on the system, that is, the catalyst chosen, the concentration of recalcitrant compounds present, the reaction temperature and other parameters [136], [137].

Although classical Fenton reactions have been widely used for the treatment of effluents, they have two major disadvantages for large scale application: the high cost of $\mathrm{H}_{2} \mathrm{O}_{2}$ generation and the narrow operating range for $\mathrm{pH}$, because iron ions precipitate as a hydroxide under certain conditions [138]. The main parameters that govern this system are the initial concentrations of $\mathrm{H}_{2} \mathrm{O}_{2}$ and $\mathrm{Fe}$ (II), and the temperature [60]. An increase in temperature is a potential solution to improve the mineralization level achieved with the same dose of $\mathrm{H}_{2} \mathrm{O}_{2}$, which greatly reduces the cost of the reaction [107]. The first catalyst systems tested were Fenton homogeneous phase systems, and have been successfully applied in the oxidation of various compounds of recalcitrant nature. Homogenous catalysis has the disadvantage of the difficulty of separating the catalyst from the stream of products after the reaction. Therefore, it becomes necessary to use the recovery operations of the catalyst, which means an increase in operating costs. An alternative solution to this problem is encapsulation of the catalyst in a porous solid, with characteristics comparable to those of homogeneous catalysts. Solid catalysts are preferred, since they can be recovered by simple separation operations and can be reused in the treatment process. The metal oxides can also be recovered from the support [139], [140]. Solid catalysts must meet some requirements, such as high activity in terms of contaminants removal, marginal leaching of the active cation, stability in a wide range of $\mathrm{pH}$ and temperature, and a high conversion of hydrogen peroxide with minimal decomposition. For practical applications, these materials must be available at a reasonable cost and their separation should be accomplished by elementary steps in a potential industrial application [141].

Fenton process and ozone treatment have been widely used in many applications and installations for treating effluents of industrial mills, in both processes the degree of mineralization achieved is highly dependent on the initial concentration of recalcitrant compounds. In general, these systems are limited to the partial oxidation of organic matter, and need to be supplemented with other AOP techniques in order to achieve the final level required. This leads to complex processes increasing the treatment costs. The nature of the organic pollutants also has a marked influence when comparing costs of Fenton and ozonation processes, the latter seems to be the most costly AOP operation [142].

To solve the determinant of production of $\mathrm{H}_{2} \mathrm{O}_{2}$ in situ and continuously, so as to achieve greater efficiency in the oxidation reactions, new methods have been developed, as photo-assisted methods with a high level of UV radiation [143], and electro-chemical processes such as electro-Fenton [144], [145]. From an energy standpoint, the application of ozone based systems seem to be more efficient for the production of radicals, considering that ozone/UV produces $\mathrm{H}_{2} \mathrm{O}_{2}$ in water, which generates more radicals, increasing the degree of mineralization. 
Table 3. Increased efficiency of COD removal by the sequence AOP- biological treatments

\begin{tabular}{|c|c|c|c|c|c|c|}
\hline \multirow{2}{*}{ Effluent } & \multirow{2}{*}{$\begin{array}{c}\text { Initial COD } \\
{\left[\mathbf{m g L}^{-1}\right]}\end{array}$} & \multicolumn{3}{|c|}{ COD Reduction [\%] } & \multirow{2}{*}{ AOP used } & \multirow{2}{*}{ Ref. } \\
\cline { 3 - 6 } & 2320 & 64 & - & 70 & ${\mathrm{UV} / \mathrm{H}_{2} \mathrm{O}_{2}}$ & {$[44]$} \\
\hline Leachate from a landfill & 2320 & 64 & - & 65 & $\mathrm{H}_{2} \mathrm{O}_{2}$ & {$[44]$} \\
\hline Leachate from a landfill & 20 & - & - & 40 & $\mathrm{O}_{3}$ & {$[76]$} \\
\hline Drinking water & 20 & - & - & 62 & $\mathrm{H}_{2} \mathrm{O}_{2} / \mathrm{O}_{3}$ & {$[76]$} \\
\hline Drinking water & 408 & - & 36 & 65 & $\mathrm{UV} /$ Fenton & {$[149]$} \\
\hline Textile & 800 & - & 33 & 95 & $\mathrm{UV} /$ Fenton & {$[150]$} \\
\hline Pharmaceutical & 500 & - & 34 & 84 & $\mathrm{UV} /$ Fenton & {$[151]$} \\
\hline Industrial & 1500 & - & 78 & 94 & Fenton & {$[152]$} \\
\hline Surfactant & 1586 & 20 & 21 & 40 & $\mathrm{O}_{3}$ & {$[82]$} \\
\hline Pulp bleaching plant & & & & &
\end{tabular}

The high operating costs associated to AOP based on $\mathrm{H}_{2} \mathrm{O}_{2}$ are highly dependent on the cost of this reactive, whereas the generation of UV radiation associated in the UV/AOP is always a small percentage of the total cost [146]. The oxidation potential of the hydroxyl radical $\left(\mathrm{E}_{0}=2.80 \mathrm{~V}\right)$ is much larger than that of the ozone $\left(\mathrm{E}_{0}=2.07 \mathrm{~V}\right)$, therefore, the combination of ozone and UV radiation and / or $\mathrm{H}_{2} \mathrm{O}_{2}$ produce hydroxyl, superoxide and perhydroxyl radicals, generating processes which synergistically accelerate the removal of organic material [147].

As there is a growing worldwide concern for the development of alternative technologies for water reuse, AOPs are considered a highly competitive technology for water treatment as they remove all organic pollutants not treatable by conventional techniques. Nevertheless, chemical oxidation for complete mineralization is usually expensive, so its combination with a biological treatment reduces operating costs [123]. Even when the mineralization of all compounds is nearly complete, AOPs need to be combined with a biodegradation process to eliminate all the organic content of a given wastewater [148]. An increased efficiency is achieved hence using the sequence: AOP- biological treatment (see Table 3).

An increased efficiency of removal of organic matter is achieved by the sequence AOP- biological treatments. It was found that the biological degradation of biodegradable compounds produced by $\mathrm{UV} / \mathrm{H}_{2} \mathrm{O}_{2}$ has a higher overall efficiency for recalcitrant compounds removal than the attainable by biological treatment followed by the same AOP [44] [153].

Acceptable levels of reduction of recalcitrant compounds were also obtained by ozone treatment as pretreatment, because the ozonation produces the breakage of large molecules, increased the system biodegradability [154]. For the economic optimization of the overall process it is necessary to limit the intensity and / or duration of the chemical treatment. Therefore, the determination of the biodegradability of the mixture of intermediate products generated during the advanced oxidation treatment is required to ensure that these combinations of strategies will reduce the overall costs of treating biodegradable effluents
[155].

To find the optimal operating conditions of the combined process, it is necessary to calculate the individual biological and chemical oxidation efficiencies. This task involves profound knowledge of both processes. Several analytical parameters must be monitored during each step of the treatment line. Chemical parameters normally measured are: COD, some specific pollutants concentrations, and inorganic species generated by the complete degradation of contaminants during the AOP treatment. Toxicity analyses and biodegradability tests are also important. In the biological system itself the measurement of anions and cations is essential since nutrients are vital to the microorganism populations in the activated sludge, and monitoring the nitrogen species provides much information related to nitrification and denitrification. This series of analytical parameters satisfies the engineering needs for the design of the combined system [156]. The efficiency of the combined process normally requires the separate optimization of both chemical and biological stages. An additional difficulty for the efficient operation of a large-scale plant, is that the chemical oxidant must not come in contact with the biological culture. Low concentrations of hydrogen peroxide are not a problem but high concentrations cause an adverse effect on the microorganisms. The reaction time of chemical oxidation is one of the most important factors to be taken into account. When the treatment is too long, the effluent is chemically overdegraded and the metabolic value of the highly oxidized products is minimal for the microorganisms. This also causes that large doses of oxidant are spent in the degradation of easily biodegradable intermediates, reducing the efficiency of the overall system [123].

\section{Conclusions}

The pulp and paper industry is a complex activity which involves many different processes and products. Pollution of water bodies is of great concern because it is an industry that generates large volumes of waste water per ton of pulp or 
paper produced, depending on the nature of the raw material, the final product and the extent of reused water.

Chemimechanical and semichemical cellulosic pulps manufacturing processes, due to their high yield, have no reactive recovery systems based on combustion of the dissolved organic matter, as indeed occurs in pulping processes such as the chemical Kraft process, and if the pulps are bleached with chlorine compounds, the effluent may have organochlorine substances.

Pollutants in these industrial effluents are highly colored, mainly due to the presence of chromophoric compounds from wood extractives, lignin derivatives and organochlorine compounds, all recalcitrant. Recalcitrant compounds are known as non-biodegradable and persist in the environment. This resistance to be degraded may be because they are not recognized as a substrate by the organisms in biological treatments; they are highly stable, that is, chemically inert due to substitutions with halogen, nitro, and sulfonate groups. They are insoluble in water, being highly toxic or either originating highly toxic degradation compounds. All these features make the biological treatment not sufficient for the removal of these compounds, so have been developed unconventional and technologically advanced treatment systems.

It is clear that advanced oxidation processes are technically applicable for the removal of recalcitrant compounds from effluents of pulp and paper mills. The merit of this technology is to improve biodegradability, reduce toxicity, enhance color removal and disposal of organic compounds, increasing the possibility of discharge those wastewaters into the receiving bodies without causing any damage. Due to the differences between the effluents from the various processes and operations of these industries, some oxidative processes must be combined to improve the efficiency of removal, though it can mean an increase in operating costs.

\section{REFERENCES}

[1] W. De los Santos Ramosa, T. Poznyaka, I. Chairezb, I. Córdova R., 2009, Remediation of lignin and its derivatives from pulp and paper industry wastewater by the combination of chemical precipitation and ozonation., Journal of Hazardous Materials, pp. 428-434.

[2] Hocking, M. B. Production of and paper. 453-504, s.1. : Handbook of Chemical Technology and Pollution Control (Third Edition), 2005.

[3] D. Pokhrel, T. Viraraghavan, 2004, Treatment of pulp and paper mill wastewater - a review, Science of the Total Environment, Vol. 333, 37- 58.

[4] M.C. Area, J.L. Valade, 1998 Revisión de los procesos de pulpado con acción química, El papel. La revista papelera para Espeña y América Latina, Vol. 69, 47-51.

[5] Muna Ali, T.R. Sreekrishnan, 2011, Aquatic toxicity from pulp and paper mill effluents: a review, Advances in
Environmental Research, Vol. 5, 175-196.

[6] B. Karrasch, O. Parra, H. Cid, M. Mehrens, P. Pacheco, R. Urrutia, C. Valdovinos, C. Zaro., 2006, Effects of pulp and paper mill effluents on the microplankton and microbial self-purification capabilities of the Biobío River, Chile. Science of The Total Environment, Volume 359, Issues 1-3, Vol. 359, 194-208 (1-3).

[7] T.G Kovacs, P.H Martel, R.H Voss, 2002, Assessing the biological status of fish in a river receiving pulp and paper mill effluents, Environmental Pollution, Vol. 118 (1), 123-140.

[8] Integrated Pollution Prevention and Control (IPPC) Reference Document on Best Available Techniques in the Pulp and Paper Industry. EUROPEAN COMMISSION. 2001.

[9] A. Ouchi, A. Saruwatari, T. Suzuki, 2008, An efficient photochemical bleaching of kraft pulps using total halogen-free reducing reagents, Journal of Photochemistry and Photobiology A: Chemistry, Vols. 193 (2-3), 122-128.

[10] M. Mohamed, M. Matayun, T. S. Lim, 1989, Chlorinated organics in tropical hardwood kraft pulp and paper mill effluents and their elimination in an activated sludge treatment system, Pertanika, Vol. 2(3), 387- 394.

[11] M.C. Area, S. A. Ojeda, O. M. Barboza, D. I. Bengoechea, F. F. Felissia, 2010, Tratamientos aplicables para la reducción de la DQO recalcitrante de efluentes de pulpado quimimecánicos y semiquímicos. (Revisión)., Rev. Cien. Tecnol., Vol. 13, 4-10.

[12] E. Magnus, G.E. Carlberg, H.H. Norske, 2000, TMP wastewater treatment including a biological high-efficiency compact reactor., Nord. Pulp Pap. Res. J, Vol. 15 (1), 29-36.

[13] C. S. Tripathi, D. G. Allen, 1999, Comparison of mesophilic and thermophilic aerobic biological treatment in sequencing batch reactors treating bleached kraft pulp mill effluent, Water Research, Vol. 33 (3), 836-846.

[14] Bajpai, P. Treatment of pulp and paper mill effluents with anaerobic technology, Randalls Road, Leatherhead, Pira International, 2000.

[15] A Kostamo, B Holmbom, J.V.K Kukkonen, 2004, Fate of wood extractives in wastewater treatment plants at kraft pulp mills and mechanical pulp mills, Water Research, Vol. 38, 972-982.

[16] M.C Diez, G Castillo, L Aguilar, G Vidal, M.L Mora, 2002, Operational factors and nutrient effects on activated sludge treatment of Pinus radiata kraft mill wastewater, Bioresource Technology, Vol. 83 (2), 131-138.

[17] T. Liu, H. Hu, Z. He, Y. Ni, 2011, Treatment of poplar alkaline peroxide mechanical pulping (APMP) effluent with Aspergillus niger, Bioresource Technology, Vol. 102 (15), 7361-7365.

[18] A.P. Buzzini, E.P. Gianotti, E.C. Pire, 2005, UASB performance for bleached and unbleached kraft pulp synthetic wastewater treatment., Chemosphere, Vol. 59 (1), 55-61.

[19] I. Akmehmet Balcıŏglu, E. Tarlan, C. Kıvılcımdan, M. Türker Saçan, 2007, Merits of ozonation and catalytic ozonation pre-treatment in the algal treatment of pulp and paper mill effluents, Journal of Environmental Management, Vol. 85 (4), 
918-926.

[20] Kyoung-Hun Kim, Son-Ki Ihm, 2011, Heterogeneous catalytic wet air oxidation of refractory organic pollutants in industrial wastewaters: A review, Journal of Hazardous Materials., Vol 186 (1), 16-34.

[21] A. Marco, S. Esplugas, G. Saum, 1997, How and why combine chemical and biological processes for wastewater treatment, Water Sci. Technol, Vol. 35 (4), 321-327.

[22] J.P. Scott, D.F. Ollis, 1995, Integration of chemical and biological oxidation processes for water treatment: review and recommendations, Environ. Prog., Vol. 14, 88-103.

[23] S.h Karimi, A. Abdulkhani, A. H. B. Ghazali, F. Ahmadun, A. Karimi, 2009, Color remediation of chemimechanical pulping effluent using combination of enzymatic treatment and Fenton reaction, Desalination, Vol. 249, 870-877.

[24] A.C. Rodrigues, M. Boroski, N.S. Shimada, J.C. Garcia, J. Nozakim, N. Hioka, 2008, Treatment of paper pulp and paper mill wastewater by coagulation-flocculation followed by heterogeneous photocatalysis, J. Photochem. Photobiol. A: Chem., Vol. 194, 1-10.

[25] P. R. Meza, F. E. Felissia, M. C. Area, 2010, Reduction of the recalcitrant cod of high yield pulp mills effluents by aop. part 1. combination of ozone and activated sludge, BioResources, Vol. 6 (2), 1053-1068.

[26] L Larrea, C.F Forster, D Melé, 1989, Changes in lignin during diffused air activated sludge treatment of kraft effluents, Water Research, Vol. 3 (9), 1073-1080.

[27] A.P Buzzini, I.K. Sakamoto, M.B. Varesche, E.C. Pires. Evaluation of the microbial diversity in an UASB reactor treating wastewater from an unbleached pulp plant, Process Biochemistry, 2006, Vol. 41 (1), 168-176.

[28] G. Thompson, J. Swain, M. Kay, C.F. Forster, 2001, The treatment of pulp and paper mill effluent: a review, Bioresource Technology, Vol. 77, 275-286.

[29] L. M. da Silva, W. F. Jardim, 2006, Trends and strategies of ozone application in environmental problems, Quim. Nova, Vol. 29 (2), 310-317.

[30] Basheer Hasan Diya'uddeen, Wan Mohd Ashri Wan Daud, A.R. Abdul Aziz, 2011, Treatment technologies for petroleum refinery effluents: A review, Process Safety and Environmental Protection, Vol. 89 (2), 95-105.

[31] C. A. Martínez-Huitle, E. Brillas, 2009, Decontamination of wastewaters containing synthetic organic dyes by electrochemical methods: A general review, Applied Catalysis B: Environmental, Vols. 87 (3-4), 105-145.

[32] R. Alnaizy, A. AkgermanU, 2000, Advanced oxidation of phenolic compounds, Advances in Environmental Research, Vol. 4, $233-244$.

[33] J. Beltran De Heredia, J. Torregrosa, J. R. Dominguez, J. A. Pere, 2001, Kinetic model for phenolic compound oxidation by Fenton's reagent, Chemosphere, Vol. 45 (1), 85-90.

[34] R. Andreozzi, V. Caprio, A. Insola, R. Marotta, 1999, Advanced oxidation processes (AOP) for water purification and recovery., Catalysis Today, Vol. 53, -59 .

[35] I. Munoz, J. Rieradevall, F. Torrades, J.Peral, X. Domenech,
2006, Environmental assessment of different advanced oxidation processes applied to a bleaching Kraft mill effluent, Chemosphere, Vol. 62, 9-16.

[36] Kati Eskelinen, Heikki Särkkä, Tonni Agustiono Kurniawan, Mika E.T. Sillanpää, 2010, Removal of recalcitrant contaminants from bleaching effluents in pulp and paper mills using ultrasonic irradiation and Fenton-like oxidation, electrochemical treatment, and/or chemical precipitation: A comparative study, Desalination, Vols. 255 (1-3), 179-187.

[37] T. A. Kurniawan, WH. Lo, 2006, Degradation of recalcitrant compounds from stabilized landfill leachate using a combination of ozone-GAC adsorption treatment, Journal of Hazardous Materials, Vol. B137, 443-455.

[38] R. Matta, K. Hanna, S. Chiron, 2007, Fenton-like oxidation of 2,4,6-trinitrotoluene using different iron minerals, Science of the Total Environment, Vol. 385, 242-251.

[39] Munter, R., 2001, Advanced oxidation processes-current status and prospects, Proc. Est.Acad. Sci. Chem, Vol. 50, 59-80.

[40] W. H. Glaze, Joon-Wun Kang, 1989, Advanced Oxidation Processes. Description of a Kinetic Model for theOxidation of Hazardous Materials in Aqueous Media with Ozone and Hydrogen Peroxide in a Semibatch Reactor, Ind. Eng. Chem. Res., Vol. 28, 1573-1580.

[41] C.P. Huang, C. Dong, Z. Tang, 1993, Advanced chemical oxidation: Its present role and potential future in hazardous waste treatmen, Waste Management, Vols. 13 (5-7), 361-377.

[42] Kyoung-Hun Kim, Son-Ki Ihm, 2011, Heterogeneous catalytic wet air oxidation of refractory organic pollutants in industrial wastewaters: A review, Journal of Hazardous Materials, Vol. 186 (1), 16-34.

[43] M. E.T. Sillanpää, T. A. Kurniawan, W. Lo, 2011, Degradation of chelating agents in aqueous solution using advanced oxidation process (AOP), Chemosphere, Vol. 83 (11), 1443-1460.

[44] G. Del Moro, A. Mancini, G. Mascolo, C. Di Iaconi, , 2013, Comparison of UV/H2O2 based AOP as an end treatment or integrated with biological degradation for treating landfill leachates, Chemical Engineering Journal, Vol. 218, 133-137.

[45] C.B. Chidambara Raj, Han Li Quen, 2005, Advanced oxidation processes for wastewater treatment: Optimization of $\mathrm{UV} / \mathrm{H} 2 \mathrm{O} 2$ process through a statistical technique, Chemical Engineering Science, Vol. 60 (19), 5305-5311.

[46] M. C. Yeber, J. Rodríguez, J. Baeza, J. Freer, C. Zaror, N. Durán, H. D. Mansilla, 1999, Toxicity abatement and biodegradability enhancement of pulp mill bleaching effluent by advanced chemical oxidation, Water Science and Technology, Vols. 40 (11-12), 337-342.

[47] S. Kommineni, J. Zoeckler, A. Stocking, S. Liang, A. Flores, M. Kavanaugh. Advanced oxidation processes. In: national water research institute. 111-208, 2008.

[48] Sandip Sharma, J.P.Ruparelia, Manish L.Patel. A general review on Advanced Oxidation Processes for waste water treatment. 382 481, Institute of Technology, Nirma University, 2011.

[49] Tratamientos avanzados de aguas residuales. Informe de 
vigilancia tecnológica Madrid. Universidad de Alcala, Círculo de Innovación en Tecnologías Mediomabientales y Energía (CITME). Villar, F. s.1. : Colección vt2, 2006, Vol. Cap 3.

[50] Ai Ni Soon, B.H. Hameed, 2011, Heterogeneous catalytic treatment of synthetic dyes in aqueous media using Fenton and photo-assisted Fenton process, Desalination, Vol. 269, $1-16$.

[51] E. Cokay Catalkaya, F. Kargi, 2007, Color, TOC and AOX removals from pulp mill effluent by advanced oxidation processes: A comparative study, Journal of Hazardous Materials, Vol. B 139, 244-253.

[52] I. Muñoz, J. Rieradevall, F. Torrades, J. Peral, X. Domènech, 2006, Environmental assessment of different advanced oxidation processes applied to a bleaching Kraft mill effluen, Chemosphere, Vol. 62, 9-16.

[53] M. Xu, Q. Wang, Y.i Hao, 2007, Removal of organic carbon from wastepaper pulp effluent by lab-scale solar photo-Fenton process, Journal of Hazardous Materials, Volume 148, Issues 1-2, Vols. 148 (1-2), 103-109.

[54] A.M. Amat, A. Arques, M.A. Miranda, F. López, 2005, Use of ozone and/or UV in the treatment of effluents from board paper industry, Chemosphere, Vol. 60 (8), 1111-1117.

[55] H.-J. Oeller, I. Demel, G. Weinberge, , 1997, Reduction in residual COD in biologically treated paper mill effluents by means of combined ozone and ozone/UV reactor stages, Water Science and Technology, Volume 35, Vols. 32 (2-3), 269-276.

[56] M. F. Sevimli, E. Deliktas, S. Sahinkaya, D. Guclu, 2013, A comparative study for treatment of white liquor by different applications of Fenton process. In press: Arabian Journal of Chemistry.

[57] N. Merayo, D. Hermosilla, L. Blanco, L. Cortijo, A. Blanco, 2013, Assessing the application of advanced oxidation processes, and their combination with biological treatment, to effluents from pulp and paper industry, Journal of Hazardous Materials, Vol. 263, 420- 427.

[58] S. Ledakowicz, M. Michniewicz, A. Jagiella, J. Stufka-Olczyk, M. Martynelis, 2006, Elimination of resin acids by advanced oxidation processes and their impact on subsequent biodegradation, Water Research, Vol. 40, 3439-3446.

[59] F. Torrades, S. Saiz, J. García-Hortal, 2011, Using central composite experimental design to optimize the degradation of black liquor by Fenton reagent, Desalination, Vol. 268, 97-102.

[60] F. Torrades, M. Perez, H. D. Mansilla, J. Peral, , 2003, Experimental design of Fenton and photo-Fenton reactions for the treatment of cellulose bleaching effluents, Chemosphere, Vol. 53, 1211-1220.

[61] M. Pérez, F. Torrades, J. A. García-Hortal, X. Domènech, J. Peral, 2002, Removal of organic contaminants in paper pulp treatment effluents under Fenton and photo-Fenton conditions, Applied Catalysis B: Environmental, Vol. 36 (1), $63-74$.

[62] I. Muñoz, J. Rieradevall, F. Torrades, J. Peral, X. Domenech, 2006, Environmental assessment of different advanced oxidation processes applied to a bleaching Kraft mill effluent,
Chemosphere, Vol. 62, 9-16.

[63] M. El-Din, D. W. Smith, F. Al Momani, W. Wang, 2006, Oxidation of resin and fatty acids by ozone: Kinetics and toxicity study., sWater Research, Vol. 40 (2), 392-400.

[64] N. Azbar, T. Yonar, K. Kestioglu, 2004, Comparison of various advanced oxidation processes and chemical treatment methods for COD and color removal from a polyester and acetate fiber dyeing effluent. 35-43, s.1. : Chemosphere, Vol. 55 .

[65] Rip G. Rice, A. Netzer. Handbook of Ozone Technology and Applications. s.1. : Ann Arbor Science, 1982.

[66] A. Alvares, C. Diaper, S. Parsons, 2001, Partial oxidation by ozone to remove recalcitrance from wastewaters - a review., Environ. Technol, Vol. 22, 409-427.

[67] F. Gokcen, T.A. Ozbelge. Pre-ozonation of aqueous azo dye (Acid Red-151) followed by activated sludge process, Chem. Eng. J, 2006, Vol. 123, 109-115.

[68] A. Chin, P.R. Berube. Removal of disinfection by-product precursors with ozone-UV advanced oxidation process, Water Research, 2005, Vol. 39, 2136-2144.

[69] V.O. Abramov, O.V. Abramov, A.E. Gekhman, V.M. Kuznetsov, G.J. Price, 2006, Ultrasonic intensification of ozone and electrochemical destruction of 1,3-dinitrobenzene and 2,4-dinitrotoluene, Ultrason. Sonochem, Vol. 13, 303-307.

[70] B. Cuiping, X. Xianfeng, G Wenqi, F. Dexin, X. Mo, G. Zhongxue, X. Nian., 2011, Removal of rhodamine B by ozone-based advanced oxidation process, Desalination, , 84-90.

[71] S. S. Abu Amr, H. A. Aziz, M. N. Adlan, M. J. Bashir, 2013, Pretreatment of stabilized leachate using ozone/persulfate oxidation process, Chemical Engineering Journal, Vol. 221, 492-499.

[72] M.R. Assalin, M.A. Rosa, N. Durán, 2004, Remediation of Kraft effluent by ozonation: effect of applied ozone concentration and initial pH, Ozone: Science and Engineering, Vol. 26, 317-322.

[73] M.-O. Buffle, U. von Gunten, 2006, Phenols and amine induced HO generation during the initial phase of natural water ozonation., Environmental Science Technology, Vol. 40 (9), 3057-3063.

[74] A.M. Amat, A. Arques, M.A. Miranda, F. López, 2005, Use of ozone and/or UV in the treatment of effluents, Chemosphere, Vol. 60, 1111-1117.

[75] T. Kreetachat, M. Damrongsri, V. Punsuwon, P. Vaithanomsat, 2007, Effects of ozonation process on lignin-derived compounds, Journal of Hazardous Materials, Vol. 142, 250-257.

[76] Fahmi, W. Nishijima, M. Okada, 2003, Improvement of DOC removal by multi-stage AOP-biological treatment, Chemosphere, Vol. 50, 1043-1048.

[77] V. Fontanier, V. Farines, J. Albet, S. Baig, J. Molinie, 2006, Study of catalyzed ozonation for advanced treatment of pulp and paper mill effluents, Water Research, Vol. 40 (2), 303-310.

[78] Chun-Han Ko, Po-Hung Hsieh, Meng-Wen Chang, Jia-Ming 
Chern, Shih-Min Chiang, Chewn-Jeng Tzeng, 2009, Kinetics of pulp mill effluent treatment by ozone-based processes., Vols. 168 (2-3), 875-881.

[79] M. Mänttäri, M. Kuosa, J. Kallas, M. Nyström, 2008, Membrane filtration and ozone treatment of biologically treated effluents from the pulp and paper industry, Journal of Membrane Science, Vols. 309 (1-2), 112-119.

[80] A. Laari, S. Korhonen, T. Tuhkanen, S. Verenich, J. Kalla, 1999, Ozonation and wet oxidation in the treatment of thermomechanical pulp (TMP) circulation waters, Water Sci. Technol, Vols. 40 (11-12), 51-58.

[81] R. S. Freire, A. Kunz, N.Duran, 2000, Some chemical and toxicological aspects about paper mill effluent treatment with ozone, Environ. Technol, Vol. 21, 717-721.

[82] L. Bijan, M. Mohsen, 2005, Integrated ozone and biotreatment of pulp mill effluent and changes in biodegradability and molecular weight distribution of organic compounds, Water Research, Vol. 39 (16), 3763-3772.

[83] A. Mounteer, J. Mokfienski, F. Amorim. Remoção de Matéria Orgânica Recalcitrante de Efluentes de Celulose Kraft de Branqueamento por Ozonólise, O Papel, Vol. 66, 64-70.

[84] P. Massa, A. Dafinov, F. Medina Cabello, R. Fenoglio, 2009, Catalytic wet peroxide oxidation of phenolic solutions over $\mathrm{Fe}_{2} \mathrm{O}_{3} / \mathrm{CeO}_{2}$ and $\mathrm{WO}_{3} / \mathrm{CeO}_{2}$ catalyst systems, Catalysis Communications, Vol. 9, 1533-1538.

[85] N. Inchaurrondo, J. Cechini, J. Font, P. Haure, 2012, Strategies for enhanced CWPO of phenol solutions., Applied Catalysis B: Environmental, Vols. 111- 112, 641- 648.

[86] Ince, N. H, 1999, "Critical" effect of hydrogen peroxide in photochemical dye degradation, Water Research, Vol. 33 (4), $1080-1084$

[87] S.J. Masten, S.H.R. Davies, 1994, The use of ozonation to degrade organic contaminants in wastewaters, Environ. Sci. Technol., Vol. 28, 180-185.

[88] F. J. Beltran, J. M. Encinar, J. F. González, 1997, Industrial wastewater advanced oxidation. Part 2. Ozone combined with hydrogen Peroxide or UV radiation, Wat. Res., Vol. 31 (10), $2415-2428$

[89] C. Zwiener, F.H. Frimme, 2000, Oxidative treatment of pharmaceuticals in water, sWater Research, Vol. 34 (6), $1881-1885$.

[90] P.Massa, A.Dafinov, R. Fenoglio , F. Medina Cabello, 2009, Degradación catalítica de fenol con peróxido de Hidrógeno: sistemas "Fenton heterogéneo", Rev Soc Quím Perú. 75 (2), Vol. 75 (2), 194-200.

[91] S. Dogruel, T. Olmez-Hanci, Z. Kartal, I. Arslan-Alatona, D. Orhon, 2009, Effect of Fenton's oxidation on the particle size distribution of organic carbon in olive mill wastewater, Water Research, Vol. 43, 3974-3983.

[92] L. Passauer, K. Fischer, F. Liebner, , 2011, Activation of pine kraft lignin by Fenton-type oxidation forcross-linking with oligo(oxyethylene) diglycidyl ether., Holzforschung, Vol. 65, 319-326.

[93] L.F. Liotta, M. Gruttadauria, G. Di Carloc, G. Perrini, V. Librando, 2009, Heterogeneous catalytic degradation of phenolic substrates: Catalysts activity, Journal of Hazardous
Materials, Vol. 162, 588-606.

[94] M. S. Lucas, J. A. Peres, 2006, Decolorization of the azo dye Reactive Black 5 by Fenton and photo-Fenton oxidation, Dyes and Pigments, Vol. 71 (3), 236-244.

[95] H. Kusic, A. Loncaric Bozic, N. Koprivanac, , 2007, Fenton type processes for minimization of organic content in coloured wastewaters: Part I: process optimization, Dyes Pigments, Vol. 74, 380-387.

[96] J.A. Zazo, J.A. Casas, A.F. Mohedano, J.J. Rodríguez, 2009, Semicontinuous Fenton oxidation of phenol in aqueous solution A kinetic study, Water Research, Vol. 43, 4063-4069.

[97] N.S. Inchaurrondo, P. Massa, R. Fenoglio, J. Font, P. Haure, 2012, Efficient catalytic wet peroxide oxidation of phenol at moderate temperature using a high-load supported copper catalyst, Chemical Engineering Journal, Vols. 198-199, 426-434.

[98] S.G. Schrank, H.J. Jose, R.F.P.M. Moreira, H.Fr. Schroder, 2005, Applicability of Fenton and $\mathrm{H} 2 \mathrm{O} 2 / \mathrm{UV}$ reactions in the treatment of tannery wastewaters, Chemosphere, Vol. 60, 644-655.

[99] Y. Xie, Z. Xiao, B. Goodell, J. Jellison, H. Militz, C. Mai, 2010, Degradation of wood veneers by Fenton's reagents: Effects of wood constituents and low molecular weight phenolic compounds on hydrogen peroxide decomposition and wood tensile strength loss, Holzforschung, Vol. 64, 375-383.

[100] V. Kavitha, K. Palanivelu, 2004, The role of ferrous ion in Fenton and photo-Fenton processes for the degradation of phenol, Chemosphere, Vol. 55, 1235-1243.

[101] B. Bianco, I. De Michelis, F. Vegliò, 2011, Fenton treatment of complex industrial wastewater: Optimization of process conditions by surface response method, Journal of Hazardous Materials, Vol. 186, 1733-1738.

[102] P. Verma, C. Mai, 2010, Hydrolysis of cellulose and wood powder treated with DMDHEU by a hydrolase enzyme complex, Fenton's reagent, and in a liquid culture of Trametes versicolor, Holzforschung, Vol. 6, 69-75.

[103] P. R Gogate, A. B Pandi, 2004, A review of imperative technologies for wastewater treatment I: oxidation technologies at ambient conditions.., Advances in Environmental Research, Vols. 8 (3-4), 501-551.

[104] Rodríguez, D. Contreras, C. Parra, J. Freer, J. Baeza, N. Durán, 1999, Pulp mill effluent treatment by Fenton-type reactions catalyzed by iron complexes. J.,: Water Science and Technology, Vols. 40 (11-12), 351-355.

[105] E.Ç. Çatalkaya, F. Karg, 2008, Advanced oxidation treatment of pulp mill effluent for TOC and toxicity removals, J. Environ. Manage., Vol. 87 (3), 396-404.

[106] E. G. Solozhenko, N. M. Soboleva, V. V. Goncharuk, 1995, Decolourization of azodye solutions by fenton's oxidation., Wat. Res., Vol. 29 (9), 2206-2210.

[107] Gema Pliego, Juan A. Zazo, Jose A. Casas, Juan J. Rodriguez, 2013, Case study of the application of Fenton process to highly polluted wastewater from power plant, Journal of Hazardous Materials, Vols. 252-253, 180-185. 
[108] M. Vilve, A. Hirvonen, M. Sillanpää, 2009, Effects of reaction conditions on nuclear laundry water treatment in Fenton process, Journal of Hazardous Materials, Vol. 164, 1468-1473.

[109] S. Navalon, M. Alvaro, H. Garcia, 2010, Heterogeneous Fenton catalysts based on clays, silicas and zeolites, Applied Catalysis B: Environmental, Vol. 99, 1-26.

[110] A.D. Bokare, W. Choi, 2014, Review of Iron-Free Fenton-Like Systems for Activating $\mathrm{H}_{2} \mathrm{O}_{2}$ in Advanced Oxidation Processes. In Press, Journal of Hazardous Materials.

[111] P.V. Nidheesh, R. Gandhimathi, 2012, Trends in electro-Fenton process for water and wastewater treatment: An overview. Desalination, Vol. 299, 1-15.

[112]Z. Wang, G. Li, Fang Yang, Y. Chen, P. Gao, 2011, Electro-Fenton degradation of cellulose using graphite/PTFE electrodes modified by 2-ethylanthraquinone, Carbohydrate Polymers, Vol. 86 (4), 1807-1813.

[113] A. Babuponnusami, K. Muthukumar, 2012, Advanced oxidation of phenol: A comparison between Fenton, electro-Fenton, sono-electro-Fenton and photo-electroFenton processes, Chemical Engineering Journal, Vol. 183, $1-9$.

[114] B. Wang, L. Gu, H. Ma, 2007, Electrochemical oxidation of pulp and paper making wastewater assisted by transition metal modified kaolin, Journal of Hazardous Materials, Vols. 143 (1-2), 198-205.

[115] C.B. Chidambara Raj, Han Li Quen, 2005, Advanced oxidation processes for wastewater treatment: Optimization of $\mathrm{UV} / \mathrm{H}_{2} \mathrm{O}_{2}$ process through a statistical technique, Chemical Engineering Science, Vol. 60 (9), 5305-5311.

[116] M. Pera-Titus, V. García-Molina, M. A. Baños, 2004, Degradation of chlorophenols by means of advanced oxidation processes: a general review, Applied Catalysis B: Environmental, Vol. 47, 219-256,.

[117] J.B. Rodríguez, A. Mutis, M.C. Yeber, J. Freer, J. Baeza, H.D. Mansilla, 1999, Chemical degradation of EDTA and DTPA in a totally chlorine free (TCF) effluent, Water Science and Technology, Vols. 40 (11-12), 267-272.

[118] N. H Ince, I. G Apikyan. Combination of activated carbon adsorption with light-enhanced chemical oxidation via hydrogen peroxide, Water Research, 2000, Vol. 34 (17), 4169-4176.

[119] P. R. Gogate, A. B. Pandit, 2004, A review of imperative technologies for wastewater treatment II: hybrid methods, Advances in Environmental Research, Vol. 8, 553-597.

[120] T. Rodriguez, D. Botelho, E. Cleto, 2008, Tratamiento de efluentes industriales de naturaleza recalcitrante usando ozono, peróxido de hidrógeno y radiación ultravioleta. Rev. Fac. Ing. Univ. Antioquia.. 24-38, Vol. 46.

[121] R. Alnaizy, A. Akgerman, 2000, Advanced oxidation of phenolic compounds., Advances in Environmental Research, Vol. 4 (3), 233-244.

[122] T. Ratpukdi, S. Siripattanakul, E. Khan, 2010, Mineralization and biodegradability enhancement of natural organic matter by ozoneeVUV in comparison with ozone, VUV, ozoneeUV, and UV: Effects of $\mathrm{pH}$ and ozone dose, Water research, Vol.

\section{4, 3531-3543.}

[123] I. Oller, S. Malato, J.A. Sánchez-Pérez, 2011, Combination of Advanced Oxidation Processes and biological treatments for wastewater decontamination-A review, Science of The Total Environment, Vol. 409 (20), 4141-4166.

[124] D. C. Botía, M. S. Rodríguez, V. M. Sarria, 2012, Evaluation of UV/TiO2 and UV/ZnO photocatalytic systems coupled to a biological process for the treatment of bleaching pulp mill effluent, Chemosphere, Vol. 89 (6), 732-736.

[125] Xiang-Rong Xu, Xiao-Yan Li, Xiang-Zhong Li, Hua-Bin L, 2009, Degradation of melatonin by UV, UV/H2O2, $\mathrm{Fe} 2+/ \mathrm{H} 2 \mathrm{O} 2$ and $\mathrm{UV} / \mathrm{Fe} 2+/ \mathrm{H} 2 \mathrm{O} 2$ processes, Separation and Purification Technology, Vols. 68 (2-5), 261-266.

[126] F. J. Benitez, J. Beltran-Heredia, J. L. Acero, F. J. Rubio, 2000, Contribution of free radicals to chlorophenols decomposition by several advanced oxidation processes, Chemosphere, Vol. 41, 1271-1277.

[127] A.M. Amat, A. Arques, F. López, M.A. Miranda, 2005, Solar photo-catalysis to remove paper mill wastewater pollutants., Solar Energy, Vol. 79 (4), 393-401.

[128] D. Hermosilla, N. Merayo, R. Ordóñez, Á. Blanco, 2012, Optimization of conventional Fenton and ultraviolet-assisted oxidation processes for the treatment of reverse osmosis retentate from a paper mil, Waste Management, Vol. 32 (6), 1236-1243.

[129] M. E.T. Sillanpää, T. A. Kurniawan, W. Lo, 2011, Degradation of chelating agents in aqueous solution using advanced oxidation process (AOP), Chemosphere, Vol. 83 (11), 1443-1460.

[130] S. Esplugas, J. Gim!enez, S Contreras, E. Pascual, 2002, Comparison of different advanced oxidation processes for phenol degradation, Water Research 36, Vol. 36, 1034-1042.

[131] M. S. Lucas, J. A. Peres, C Amor, L Prieto-Rodríguez, M I. Maldonado, S Malato, 2012, Tertiary treatment of pulp mill wastewater by solar photo-Fenton., Journal of Hazardous Materials, Vols. 225-226, 173-18.

[132] T. S. Jamil, M. Y. Ghaly, I. E. El-Seesy, E. R. Souaya, R. A. Nasr, 2011, A comparative study among different photochemical oxidation processes to enhance the biodegradability of paper mill wastewater, Journal of Hazardous Materials, Vol. 185, 353-358.

[133] J. L. Tambosi, M. Di Domenico, R. F. P. M. Moreira. Pre-oxidation and coagulation of paper and pulp wastewater by fenton-like process. Departamento de Engenharia Química e Engenhari Federal de Santa Catarin2nd Mercosur Congress on Chemical Engineering, 4th Mercosur Congress on Process Systems Engineering.

[134] M. Faouzi, P. Cañizares, A. Gadri, J. Lobato, B. Nasr, R. Paz, M.A. Rodrigo, C. Saez, 2006, Advanced oxidation processes for the treatment of wastes polluted with azoic dyes, Electrochimica Acta, Vol. 52 (1), 325-331.

[135] B. Gözmen, B. Kayan, A. Murat Gizir, A. Hesenov, 2009, Oxidative degradations of reactive blue 4 dye by different advanced oxidation methods, Journal of Hazardous Materials, Vol. 168, 129-136.

[136] S.G. Schrank, H.J. Jose, R.F.P.M. Moreira, H.Fr. Schroder, 2005, Applicability of Fenton and $\mathrm{H} 2 \mathrm{O} 2 / \mathrm{UV}$ reaction in the 
treatment of tannery wastewaters, Chemosphere, Vol. 60, 644-655.

[137] H. Zangeneh, A.A.L. Zinatizadeh, M. Feizy. A comparative study on the performance of different advanced oxidation processes $\left(\mathrm{UV} / \mathrm{O}_{3} / \mathrm{H}_{2} \mathrm{O}_{2}\right)$ treating linear alkyl benzene (LAB) production plant's wastewater. In press. Journal of Industrial and Engineering Chemistry, 2013.

[138] C. Ciotti, R. Baciocchi, T. Tuhkane, 2009, Influence of the operating conditions on highly oxidative radicals generation in Fenton's systems, Journal of Hazardous Materials, Vol. 161 (1), 402-408.

[139] H. Al-Sheeha, M. Marafi, A. Stanislaus, 2008, Reclamation of alumina as boehmite from an alumina-supported spent catalyst. ., Int. J. Miner. Process, Vol. 88, 59-64.

[140] G. Cao, M. Sheng, W. Niu, Y. Fei, D. Li, 2009, Regeneration and reuse of iron catalyst for Fenton-like reactions, Journal of Hazardous Materials, Vol. 172, 1446-1449.

[141] F. Larachi, S. Lévesque, A. Sayari, 1998, Wet oxidation of acetic acid by $\mathrm{H}_{2} \mathrm{O}_{2}$ catalyzed by transition metal-exchanged $\mathrm{NaY}$ zeolites., J. Chem. Technol. Biotechnol, Vol. 73, 127-130.

[142] P. Cañizares, R. Paz, C. Sáez, M. A. Rodrigo, 2009, Costs of the electrochemical oxidation of wastewaters: A comparison with ozonation and Fenton oxidation processes, Journal of Environmental Management, Vol. 90 (1), 410-420.

[143] T. Coenen, W. Van de Moortel, F. Logist, J. Luyten, J. F.M. Van Impe, J. Degrèv, 2013, Modeling and geometry optimization of photochemical reactors: Single- and multi-lamp reactors for $\mathrm{UV}-\mathrm{H}_{2} \mathrm{O}_{2}$ AOP systems, Chemical Engineering Science, Vol. 96 (7), 174-189.

[144] X. Liu, X. Sun, D. Li, W. Li, Y. Huang, G. Sheng, H. Yu, 2012, Anodic Fenton process assisted by a microbial fuel cell for enhanced degradation of organic pollutants.., Water Research, Vol. 46 (14), 4371-4378.

[145] M. A. Oturan, N. Oturan, M. C. Edelahi, F. I. Podvorica, K. El Kacemi, 2011, Oxidative degradation of herbicide diuron in aqueous medium by Fenton's reaction based advanced oxidation processes, Chemical Engineering Journal, Vol. 171 (1), 127-135.

[146] E. J. Rosenfeldt, K. G. Linden, S. Canonica, U. Gunten, 2006, Comparison of the efficiency of radical dotOH radical formation during ozonation and the advanced oxidation processes $\mathrm{O}_{3} / \mathrm{H}_{2} \mathrm{O}_{2}$ and $\mathrm{UV} / \mathrm{H}_{2} \mathrm{O}_{2}$., Water Research, Vol. 40 (20), 3695-3704
[147] M. S. Lucas, J. A. Peres, G. Li Puma, 2010, Treatment of winery wastewater by ozone-based advanced oxidation processes $\left(\mathrm{O}_{3}, \mathrm{O}_{3} / \mathrm{UV}\right.$ and $\left.\mathrm{O}_{3} / \mathrm{UV} / \mathrm{H}_{2} \mathrm{O}_{2}\right)$ in a pilot-scale bubble column reactor and process economic, Separation and Purification Technology, Vol. 72 (3), 235-241.

[148] S. Parra, S. Malato, C. Pulgarín, 2002, New integrates photocatalytic-biological flow system using supported $\mathrm{TiO}_{2}$ and fixed bacteria for the mineralization of isoproturon, Applied Catalysis B: Environmental, Vol. 36, 131-144.

[149] D. R. Manenti, A. Módenes, P. Soares, F. Espinoza-Quiñones, R. Boaventura, R. Bergamasco, V. Vilar. Assessment of a multistage syste based on electrocoagulation, solar photo Fenton and biological oxidation processes for real textile wasterwater. In Press, Chemical Engineering Journal, 2014.

[150] C. Sirtori, A. Zapata, I. Oller, W. Gernjak, A. Aguera, S. Malato, 2009, Decontamination industrial pharmaceutical wastewater by combining solar photo-Fenton and biological treatment.., Water Research, Vol. 43, 661-668.

[151] A. Zapata, I. Oller, C. Sirtori, A. Rodríguez, J. Sánchez-Pérez, A. Lopez, M. Mezcua, S. Malato, 2010, Decontamination of industrial wastewater containing pesticides by combining large-scale homogeneous solar photocatalysis and biological treatment., Chemical Engineering Journal, Vol. 160, $447-456$.

[152] X.-J. Wang, Y. Song, J.-S. Mai, 2008, Combined Fenton oxidation and aerobic biological processes for treating a surfactant wastewater containing abundant sulfate., Journal of Hazardous Materials, Vol. 160, 344-348.

[153] R. Toor, M. Mohsen, 2007, UV-H2O2 based AOP and its integration with biological activated carbon treatment for DBP reduction in drinking water, Chemosphere, Vol. 66 (11), 2087-2095.

[154] Fahmi, W. Nishijima, M. Okada, 2003, Improvement of DOC removal by multi-stage AOP-biological treatment, Chemosphere, Vol. 50 (8), 1043-1048.

[155] M.M. Ballesteros Martín, J.L. Casas López, I. Oller, S. Malato, J.A. Sánchez Pérez, 2010, A comparative study of different tests for biodegradability enhancement determination during AOP treatment of recalcitrant toxic aqueous solutions, Ecotoxicology and Environmental Safety, Vol. 73 (6), 1189-1195.

[156] S. Malato, P. Fernández-Ibañez, M.I. Maldonado, J. Blanco, W. Gernjak, 2009, Decontamination and disinfection of water by solar photocatalysis: recent overview and trends, Catalysis Today, Vol. 147, 1-59. 